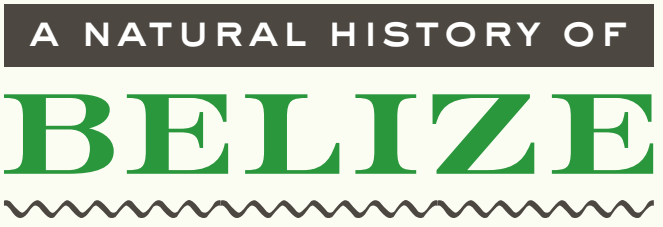


NUMBER FIFTY-TWO

The Corrie Herring Hooks Series

\section{A NATURAL HISTORY OF}

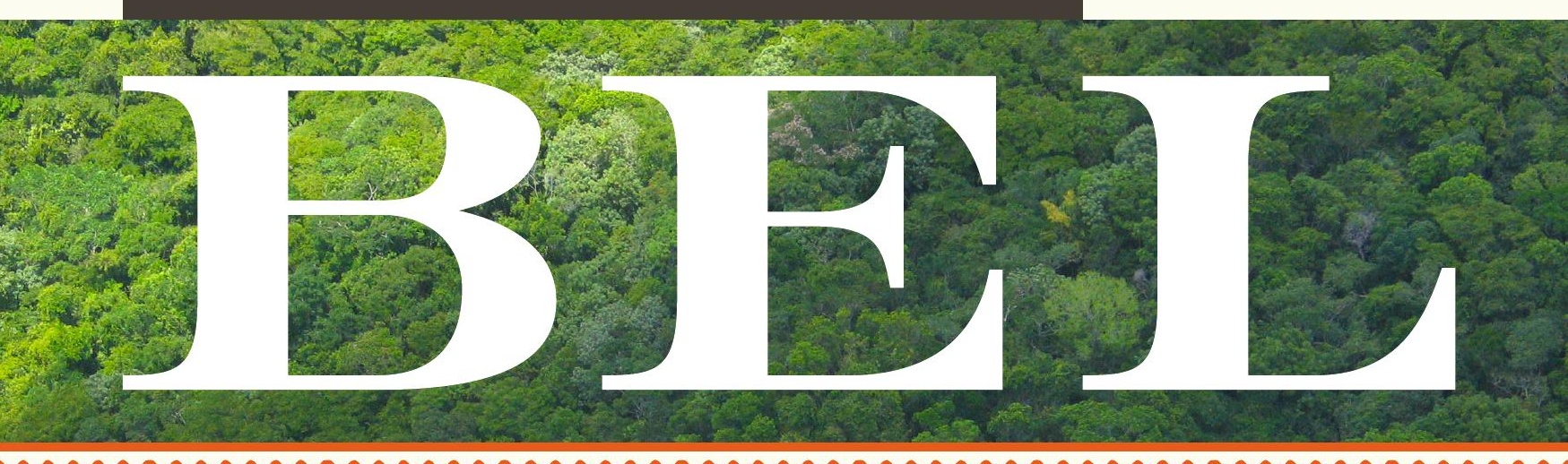




\section{SAMUEL BRIDGEWATER}

Foreword by Stephen Blackmore

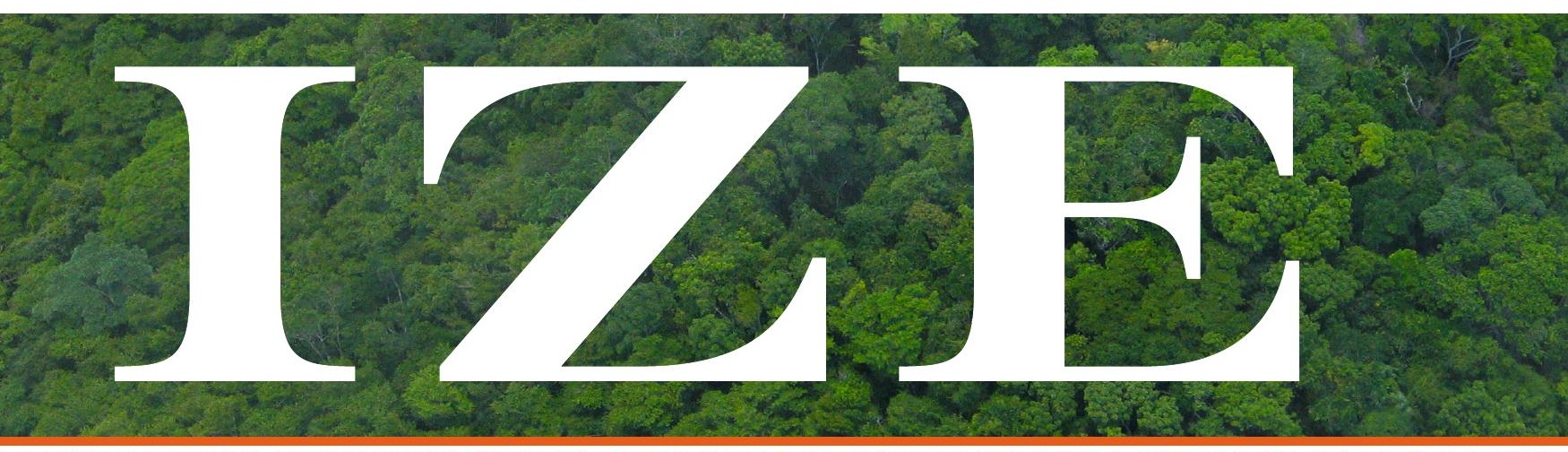

INSIDE THE MAYA FOREST

UNIVERSITY OF TEXAS PRESS, AUSTIN

in association with the

NATURAL HISTORY MUSEUM, LONDON 
Copyright (C) 2012 by the Natural History Museum, London All rights reserved

Printed in China

First edition, 2012

Requests for permission to reproduce material from this work should be sent to:

Permissions

University of Texas Press

P.O. Box 7819

Austin, TX $_{78713-7819}$

www.utexas.edu/utpress/about/bpermission.html

The paper used in this book meets the minimum requirements of Ansi/NISO Z39.48-1992 (R1997) (Permanence of Paper). @)

Designed by Lindsay Starr

LIBRARY OF CONGRESS CATALOGING-IN-PUBLICATION DATA

Bridgewater, Samuel, 1968-

A natural history of Belize : inside the Maya forest / Samuel Bridgewater ; foreword by Stephen Blackmore. - 1st ed.

p. $\quad$ cm. - (The Corrie Herring Hooks series; no. 52) Includes bibliographical references and index.

ISBN 978-0-292-72671-o (cloth : alk. paper)

1. Natural history-Belize. 2. Forests and forestry-Belize.

3. Land use-Belize-History. I. Title.

QH108.B43B75 2011

$508.7282-\mathrm{dc} 23$

2011024357

ISBN 978-0-292-73900-o (e-book) 